\title{
Pandangan Para Ahli Bahasa tentang Bahasa Serapan dalam al-Quran
}

\author{
DOI 10.18196/AIIJIS.2015. 0041.1-27
}

\section{MAHYUDIN RITONGA}

Fakultas Agama Islam, Universitas Muhammadiyah Sumatera Barat

E_mail: mahyudinritonga@gmail.com

\section{ABSTRACT}

This article explains some words in the Qur' an which are believed to have been taken from non Arabic word. Whether or not the Quran comprises non Arabic words, and whether the Qur'an has Arabized some foreign an non Arabic words has been stimulated debate among scholars. Some ulama (Islamic scholars) believe that the Quran only embraces Arabic word. But some others argue that there are some words in the Qur'an which are not recognized in Arabic language, and they also suggests that this is a kind of weakness of the Qur'an. This article focuses on how arabisation process has taken place furing the formation of the Qur'an as a corpus.

\section{ABSTRAK}

Tulisan ini menjelaskan kosa kata yang dianggap merupakan serapan dari bahasa selain Bahasa Arab. Motivasi dalam melakukan analisis terhadap masalah ini tidak terlepas dari kontroversi pemahaman terhadap fenomena arabisasi beberapa kosakata yang terdapat di dalam al-Quran, sebahagian ahli berpendapat tidak mungkin al-Quran menggunakan bahasa selain Bahasa Arab sementara pendapat sebahagian yang lain berpendapat bahwa banyak di antara kosakata yang ada di dalam al-Quran yang bukan berBahasa Arab dan hal ini merupakan bukti kelemahan al-Quran dan kecolongan bagi umat Islam. Untuk mendapatkan pemahaman yang komprehensif dan mendalam terhadap permasalahan arabisasi merupakan kajian yang penting untuk dilakukan.

Keyword: ahli, serapan, kosa kata al-Quran.

\section{PENDAHULUAN}

Pembahasan apakah terdapat kosa kata serapan dari bahasa asing dalam al-Quran merupakan sebuah kajian penting, karena otensitas bahasa al-Quran pada saat ini mulai dipertanyakan banyak orang, terutama dari kalangan orientalis. Di dalam al-Quran sendiri terdapat setidaknya sepuluh ayat yang 
mengisyaratkan bahwa al-Quran itu berBahasa Arab. ${ }^{1}$ beberapa kitab tafsir klasik yang bercorak atsar, seperti Jami' al-Bayan, maupun tafsir modern yang lebih banyak memberikan analisis pemikiran, seperti Tafsir fi Zilal al-Quran dan Tafsir al-Mannar, memaknai kata 'Arabiy yang terdapat di dalam al-Quran dengan "Bahasa Arab". 2

Al-Quran dan Bahasa Arab adalah ibarat dua sisi mata uang yang tidak dapat dipisahkan antara satu dengan yang lainnya. Al-Quran adalah kitab Allah yang diturunkan dengan Bahasa Arab, sementara itu Bahasa Arab adalah bahasa yang selalu hidup dan berkembang, dan perkembangan Bahasa Arab itu tidak terlepas dari pengaruh al-Quran yang berbahasa Arab. Dalam kaitan Bahasa Arab dengan al-Quran tergambar ketidakkonsistenan di antara beberapa kalangan akademisi terhadap pemahaman hubungan bahasa dengan budaya, seperti halnya menghilangkan budaya Arab dalam membaca al-Quran sebagaimana yang terjadi belakangan ini.

Fokus pembahasan tulisan ini adalah untuk mencari jawaban tentang apakah di dalam al-Quran ditemukan kosa kata selain Bahasa Arab. Bila memang terdapat kosa kata lain selain Bahasa Arab, lantas bagaimana pandangan orientalis terhadap kosa kata tersebut, dan bagaimana pula pandangan ulama baik dari kalangan linguis, ahli tafsir, dan ahli fiqih terhadap keberadaan kata serapan di dalam al-Quran. Sebagai jawaban dari permasalahan di atas, maka cakupan tulisan ini adalah, a. Pengertian Bargaining Bahasa, b. al-Quran dan Bahasa Arab, c. Kosa Kata Asing di dalam al-Quran, d. Pandangan Orientalis terhadap Bahasa al-Quran, e. Pendapat Para Ulama terkait persoalan penyerapan kata di dalam al-Quran. Dalam uraiannya, tulisan ini menggunakan analisis deskriptif dan komparatif. Sementara sumber bacaan yang penulis gunakan ialah buku-buku yang mengkaji tentang penyerapan bahasa, seperti Fiqh alLughah, serta tafsir dan ‘Ulumul Quran.

\section{PEMBAHASAN}

\section{Pengertian Bargainining Bahasa}

Bargaining bahasa merupakan fenomena penyerapan suatu bahasa kepada bahasa tertentu. Menurut Haugen semua tipe penyerapan meliputi dua kutub proses, yakni prosess importation dan proses substitution. ${ }^{3}$ Weinreich mengatakan bahwa pengaruh bahasa lain kepada bahasa tertentu merupakan difusi dan akulturasi budaya. ${ }^{4}$ Sementara itu, istilah kata serapan dalam Bahasa Arab lebih populer dengan istilah ta'rib. 
Adapun pemhaman terhadap fenomena ta'rib di dalam Bahasa Arab ialah telah banyak linguis Arab yang telah memberikan interpretasi sesuai dengan bidang dan kompetensi mereka. Ya'qub memuat dalam bukunya definisidefinisi yang dibuat oleh para pakar kebahasaan Arab, di antaranya ان تتكلم العرب بالكلمة الأعجمية على نهجهاو اصلوبها (Manakala orang Arab menyebut atau mengatakan satu kata dari bahasa asing yang berlandaskan pada cara dan sisitem bahasanya), ataul ان تتكلم العرب بالكلمة الأعجمية مطلق (Manakala orang Arab menyebut atau mengatakan satu kata dari bahasa asing secara mutlak). Definisi lain adalah:نقل الكلمة من العجمية الى العربية "artinya: transfer kata dari bahasa asing ke Bahasa Arab. Atau juga disebut:نقل الكلمة من العجمية الى العربية (Kosa-kata asing yang telah dirubah orang Arab menjadi bahasa mereka dengan cara pengurangan, penambahan, dan pembalikan. ${ }^{5}$

Secara istilah, kata-kata yang diserap dan dipinjam oleh Bahasa Arab dari bahasa-bahasa lain disebut dengan mu'arrob, dan tentunya melalui proses perpindahan serta perubahan yang disebut dengan ta'rib atau Arabisasi. ${ }^{6}$ Dengan demikian, pengertian kata serapan dan ta'rib adalah sama, yaitu fenomena suatu bahasa yang menyerap bahasa lain.

Biasanya, kata-kata asing satu bahasa masuk ke bahasa lain disebabkan oleh faktor-faktor berikut: kedekatan letak geografis, hubungan perdagangan, imigrasi, kekuasaan politik, kecenderungan religius, kultur, ekonomi, indrustri, dan lain-lain. Intinya, faktor-faktor ini adalah faktor yang berakar dari tuntutantuntutan material dan spiritual manusia. Itulah sebabnya mengapa terjadi proses serapan kata. Sejalan dengan perkembangan peradaban, budaya pun melalui waktu yang cukup panjang dalam sejarah manusia dan proses serapan meningkat luar biasa sehingga dapat dikatakana bahwa tidak ada lagi bahasa hidup dunia yang masih murni. Tidak ada pula bangsa yang berani mengaku bahwa bahasa mereka bersih dari unsur-unsur asing serapan atau pinjaman dari bahasa bangsa lain.

Sesuai dengan adanya interaksi antar bangsa, maka tidak ada satu bahasa pun yang tidak menyerap bahasa lain, baik dari segi kosa katanya, maupun dialek-dialeknya. Pernyataan ini berdasarkan ungkapan Gonda yang mengatakan bahkan bahasa Inggris yang merupakan bahasa terkemuka, menyerap tidak kurang dari setengah kosa katanya dari bahasa Latin, Yunani, Skandinavia dan Prancis. ${ }^{7}$

Bahasa Arab juga tidak terhindar dari proses serapan kata. Karena bangsa Arab pra Islam sendiri sebagaimana disinyalir oleh Ramadan Abduttawwab, ${ }^{8}$ juga telah melakukan interaksi dengan masyarakat di luar Arab, seperti Persi, 
Akhbas, Romawi, Suryani, Nabti. Pernyataan yang sama juga diungkapkan 'Abd al-Wahid Wafi, la mencontohkan salah bentuk hubungan politik dan perdagangan antara Arab dengan tetangganya, yaitu hubungan yang terjalin antara Arab dengan 'Aramiyyin. ${ }^{9}$

Kondisi ini tentu akan berdampak pada saling keterpengaruhan antar sesama bangsa yang saling berinteraksi tersebut, terutama keterpengaruhan dalam bidang bahasa. ${ }^{10}$ Namun, yang lebih menjadi persoalan adalah apakah al-Quran yang diwahyukan kepada Muhammad dengan Bahasa Arab fasih yang populer di kawasan Hijaz pada waktu itu juga memakai kata-kata asing? Yang harus digaris bawahi adalah sesungguhnya keterbukaan sebuah bahasa untuk menerima atau menyerap kata-kata asing maupun daerah tidak berarti mempertaruhkan kesejatian bahasa atau harga diri suatu bangsa yang berbahasa.

\section{Al-Quran dan Bahasa Arab}

Al-Quran dikenal dengan kemukjizatan bahasanya (al-i'jaz al-lughawi). Bahasa dimaksud adalah Bahasa Arab, karena al-Quran diturunkan dalam Bahasa Arab. Kemukjizatan al-Quran dari segi bahasa bahkan dapat disebutkan menjadi pokok kemukjizatannya, karena melalui kemukjizatan dari segi bahasa, al-Quran menantang orang-orang kafir untuk menciptakan bahasa yang indah seperti bahasa al-Quran. ${ }^{11}$ Keindahan bahasa al-Quran, misalnya dicatat oleh Abdullah Darraz yang mengatakan bahwa "Bila engkau membuka al-Quran, lalu membukanya lagi, maka engkau akan mendapatkan makna lain dari yang sebelumnya."12

Salah satu karakteristik bahasa al-Quran adalah konteks keberadaannya yang terkait erat dengan kehidupan bangsa Arab dan nilai-nilai budaya yang mereka anut. al-Quran hadir tidak pada ruang kosong, tetapi interaktif dengan bangsa Arab. Kehidupan perniagaan bangsa Arab sebagai karakteristik terpenting, misalnya banyak disinggung oleh al-Quran; begitu juga meyangkut nilai-nilai moral, agama, dsb. Terkait contoh perniagaan, khususnya, pada penghujung abad ke-6, para pedagang besar kota Makkah, telah memperoleh kontrol monopoli atas perniagaan yang lewat bolak-balik dari pinggiran pesisir barat Arabia ke Laut Tengah. Kafilah-kafilah dagang yang biasanya pergi ke Selatan di musim dingin dan ke Utara di musim panas, dirujuk dalam alQuran (106: 2). Rute ke Selatan adalah ke Yaman, tetapi biasanya juga diperluas ke Abisinia; sementara rute ke Utara adalah ke Siria. Di tangan kafila-kafilah 
inilah orang-orang Makkah mempertaruhkan eksistensinya yang asasi. Di lembah kota Makkah yang tandus, pertanian maupun peternakan adalah impian indah di siang bolong. Kota ini sangat bergantung pada impor bahan makanan. Karena itu, kehidupan ekonominya yang khas adalah di bidang perniagaan dan kemungkinan besar hanya bersifat moneter. ${ }^{13}$

Pada kenyataannya, sisi kehidupan perniagaan bangsa Arab ini terkait atau dilandasi oleh soal keyakinan. Ungkapan-ungkapan dari dunai perniagaan memang menghiasi lembaran-lembaran al-Quran dan digunakan untuk mengungkap ajaran-ajarannya yang asasi. Hisab suatu istilah yang lazim digunakan untuk perhitungan untung rugi dalam dunia perniagaan, muncul di bebepara tempat dalam al-Quran sebagai salah satu nama bagi Hari Kiamat (yaum al-hisab), ketika perhitungan terhadap segala perbuatan manusia dilakukan dengan dengan sangat cepat (sari' al-hisab). Sementara kata hasib (pembuat perhitungan, penghitung) dinisbatkan kepada Tuhan dalam kaitnnya dengan perbuatan manusia. Gagasan utama yang mendasari 'perhitungan' ilahi adalah kitab, yang merekam segala perbuatan baik dan buruk manusia. Timbangan akan dipasang di Hari Perhitungan dan seluruh perbuatan manusia akan ditakar. Setiap orang akan bertanggungjawab atas segala perbuatan yang telah dilakukannya. Perbuatan baik dan direstui akan memperoleh imbalan atau upah; sebaliknya, perbuatan buruk dan dikutuk akan diganjar azab neraka. Kata-kata kerja kasab (memperoleh keuntungan, berusaha, berbisnis), jaza (membayarkan, memberi upah, ganjaran, imbalan) ajara (memberi upah, membayar nilai kontrak, imabalan), serta bentuk konjugasinya, sering digunakan al-Quran dalam konteks-konteks semacam ini. ${ }^{14}$

Contoh lain dari bagaimana kata-kata al-Quran merefleksikan budaya Arab adalah perihal konsep ketuhanan yang dalam al-Quran, misalnya, disebut dengan di antaranya kata-kata Allah, al-Malik, al-Rahman, dan al-Rahim. Ilmuwan Islam terkenal, Isma'il al-Faruqi, sebagaimana dikutip oleh Nurcholis Madjid, misalnya, menulis panjang lebar sebagai berikut:

Inskripsi Arabia Selatan (Ma'in, Saba' dan Qathaban), begitu pula Arabia Utara (Lihyan, Tsamud, dan Shafa) memberi bukti bahwa suatu dewa maha tinggi (supreme deity) yang disebut al-Ilah atau Allah telah disembah sejak masa dahulu kala. Dewa ini mengairi tanah, membuat palawija tumbuh, rajakaya berkembang biak, dan sumber air serta sumur mengeluarkan air yang memberi hidup. Di Makkah, juga di seluruh Jazirah Arabia, "Allah" diakui sebagai "Pencipta dari semuanya", "Pangeran seluruh alam", "Penguasa langit bumi", Pengawas tertinggi segala- 
galanya". "Allah" adalah nama dewa yang paling banyak disebut. Tetapi, fungsiNya didelegasikan atau diambil alih oleh dewa-dewa lain yang lebih kecil; dan pengaruhnya yang luar biasa dinyatakan dalam matahari dan rembulan, misalnya. Kualitas-kualitasNya dijelmakan dan digantikan ke dalam dewa-dewa atau dewi-dewi selain daripadaNya (Allah). Dengan begitu timbullah sejumlah pantheon yang setiap anggotanya memperhatikan sama juga suatu kebutuhan tertentu atau suku tertentu dan mewakili suatu ciri khusus, tempat, obyek, atau kekuatan yang menunjukkan kehadiran, perhatian, dan kekuasaanNya yang bersifat llahi. Allat, sebagaseorang dewi, digambarkan sebagai anak perempuan Allah dan diidentifikasikan dengan matahari oleh sebagian, dengan rembulan oleh yang lain. Al-Uzza adalah seorang anak perempuan ilahi yang kedua, yang dihubungkan dengan planet Venus; Maniat, anak perempuan ketiga, mewakili nasib. Dzu al-Syara' dan Dzu al-Khalashah adalah dewa-dewa yang mengambil nama dari tempat-tempat ramalan nasib; Dzu al-Kaffayn Dzu al-Rijl diasosiasikan dengan anggota badan yang mempunyai makna tertentu, meskipun tidak diketahui. Wudd, Yaghuts, Ya'uq dan Suwa adalah dewa-dewa yang mengambil nama dari fungsi-fungsi ketuhanan untuk, berturut-turut, cinta, pertolongan, perlindungan, dan penerapan siksa yang pedih. Dewa Hubal, yang memiliki patung paling menonjol di Kabah mempunyai tangan yang terbuat dari emas murni. Al-Malik (Raja), Al-Rahman (Pengasih), dan al-Rahim (Selamanya Pengasih) mengidentifikasi dewa-dewa atau barangkali mewakili fungsi-fungsi ketuhanan maha tinggi dari suatu dewa dengan suatu nama yang lain. ${ }^{15}$ Selain konteks keterkaitannya dengan budaya Arab, karakteristik bahasa al-Quran yang dapat disebutkan di sini adalah beberapa kosakatanya yang orang Arab tidak langsung mengetahui maknanya (gharib), kecuali sesudah mereka mencari maknanya pada puisi atau syair Arab. Al-Suyuthiy, misalnya mencatat kurang lebih 199 kosakata al-Quran yang dinilainya gharib, dan sebagaimana dinyatakan oleh Ibnu Abbas hendaknya dicari pengertianya pada puisi-puisi Arab karena syair merupakan khazanah bangsa Arab (diwan al'arab). ${ }^{16}$

Beberapa pendapat di atas menunjukkan bahwa Bahasa Arab merupakan bahasa yang tidak dapat dipisahkan dengan al-Quran. Untuk melihat bagaimana hubungan Bahasa Arab dengan al-Quran secara ilmiah berikut diungkapkan beberapa argumen yang mendasarinya:

1. Bahasa Arab merupakan bahasa tertua yang masih eksis 
Secara historis Bahasa Arab termasuk salah satu dari rumpun bahasa Semit. Ada banyak tokoh dengan pernyataan yang sama; bahwa Bahasa Arab merupakan salah satu rumpun bahasa semit. Masnal Zajuli, dalam al-Ishtirak fi al-Lughah al-Arabiyyah menyatakan al-Lughah al-'Arabiyyah al-Samiyyah. ${ }^{17}$ Lebih jauh dari itu, Ya'qub, setelah menganalisa berbagai pendapat terkait Bahasa Arab sebagai salah satu bahasa semit, lalu dia menyimpulkan bahwa Bahasa Arab adalah bahasa yang paling dekat dengan bahasa proto semit (al-Umm al-Samit). ${ }^{18}$

Shihab dalam bukunya Mukjizat al-Quran juga menyatakan bahwa Bahasa Arab termasuk rumpun bahasa Semit, ${ }^{19}$ sama dengan bahasa Babilonia, 'Asuriya, Aramy, Ibrani, Yaman lama, Habshi Semit dan Bahasa Arab itu sendiri. Ketiga bahasa yang pertama telah lenyap, demikian pula sebagian dari bahasa-bahasa Yaman lama. Sedangkan tiga yang terakhir masih ada, tetapi Bahasa Arab adalah bahasa yang paling menonjol dan paling luas penyebarannya. Realita inilah yang menjadi salah satu penyebab keunggulan Bahasa Arab dari bahasa lainnya, sampai saat ini masih "hidup" dan menjadi alat berkomunikasi resmi, setidaknya oleh masyarakat yang tinggal di kawasan Jazirah Arab dan Asia Tengah.

2. Bahasa Arab merupakan bahasa Terkaya

Sebagai salah satu bahasa tertua wajarlah bila Bahasa Arab memiliki jumlah kosa kata yang paling banyak. Selain itu, Bahasa Arab dikenal memiliki banyak kelebihan, di antaranya: (1) Sejak dahulu hingga sekarang Bahasa Arab merupakan bahasa yang hidup, (2) Bahasa Arab adalah bahasa yang lengkap dan luas untuk menjelaskan tentang ketuhanan dan keakhiratan, (3) Bentuk-bentuk kata dalam Bahasa Arab mempunyai tasrif yang amat luas hingga dapat mencapai 3000 bentuk perubahan, ${ }^{20}$ yang demikian itu tidak terdapat dalam bahasa lain.

3. Bahasa Arab sebagai Penunjang Kekekalan al-Quran

Tiga kesatuan poin agama Islam, risalah Islam, kitab (al-Quran) dan Rasul (Muhammad). karena Islam adalah risalah yang universal dan kekal, maka mukjizatnya harus retoris dan linguistis. Dan Allah telah berjanji untuk memeliharanya, seperti ditegaskan-Nya: "Sesungguhnya Kami yang menurunkan al-Dhikra (al-Quran) dan Kami pula yang memeliharanya." (QS. 15: 9). Untuk itu diperlukan sebuah bahasa khusus yang bisa menampung informasi risalah secara abadi. Sebab para pengamat sejarah bahasa sepakat bahwa setiap bahasa itu punya masa eksis yang terbatas. Lewat dari masanya, maka bahasa itu tidak lagi dikenal atau bahkan hilang 
dari sejarah sama sekali. Harus ada sebuah bahasa yang bersifat abadi dan tetap digunakan oleh sejumlah umat manusia sepanjang masa. Bahasa itu ternyata menurut pakar bahasa adalah Bahasa Arab, sebagai satu-satunya bahasa yang pernah ada di muka bumi yang sudah berusia ribuan tahun dan hingga hari ini masih digunakan oleh banyak orang.

\section{Bargaining dalam al-Quran dan Cara Mengetahuinya}

Salah satu persoalan yang sampai sekarang masih diperdebatkan oleh para ahli bahasa dan sastra Arab serta mufasir adalah apakah kosa kata serapan dari bahasa asing dipakai dalam al-Quran atau tidak? Dengan kata lain, apakah semua kata yang digunakan dalam al-Quran adalah Bahasa Arab asli atau ada juga kata-kata yang telah melalui proses pengaraban?

Kata-kata gharib dalam al-Quran ini menurut Mushthafa Shadiq al-Rafii bukanlah berarti kata-kata tersebut tidak diketahui (munkirat), jarang (nafirat), atau janggal (syadzat) karena al-Quran terhindari dari semua itu, tetapi katakata yang tidak mungkin untuk ditawilkan karena pengetahuan orang yang tidak dapat menjangkaunya:

اللفظية هنا هي التي تكون حسنة مستغربة في التأويل بحيث لا يتساوى في العلم بها أهلها وسائر الناس 21

Selanjutnya al-Rafii mengatakan bahwa latar belakang munculnya bahasabahasa gharib dalam al-Quran ini adalah bisa jadi berasal dari bahasa-bahasa yang berbeda (lughat mutafarriqat), atau bahasa non Arab yang diarabkan oleh orang Arab dan kemudian dipakai oleh al-Quran. ${ }^{22}$ Dalam wacana ilmuilmu al-Quran ('Ulum al-Quran), bahasa-bahasa yang berbeda di atas terkait dengan konsep penurunan al-Quran dengan "Tujuh Huruf" (sab'atu ahruf) berdasarkan banyak riwayat hadis. ${ }^{23}$ Salah satu pendapat tentang sab'atu ahruf yang perlu dikemukakan di sini adalah bahwa lafaz-lafaz yang terdapat dalam al-Quran tidak lepas dari tujuh bahasa yang terkenal di kalangan bangsa Arab. Dalam hal ini, bahasa Quraisy lebih dominan, sementara bahasa lainnya adalah Huzail, Saqif, Hawazin, Kinanat, Tamim, dan Yaman. ${ }^{24}$ Sebagai contoh dalam dalam hal ini, adalah Umar bin Khatthab yang pernah bertanya tentang arti kata takhawwuf (QS, 16: 47), yang kemudian seorang pimpinan Suku Huzail berkata bahwa kata tersebut adalah bahasa sukunya, yang berarti pengurangan (al-tanaqqush). ${ }^{25}$

Penyerapan kata dari bahasa lain adalah hal yang sangat lumrah dan pasti terjadi pada semua bahasa. Karena sebenarnya menurut para ahli bahasa, antara satu bahasa dengan bahasa lain saling terkait secara historis. Bahkan sebenarnya, menurut mereka, tiap-tiap bahasa punya induk dan tiap-tiap induk 
sebenarnya berasal dari satu sumber. Sebut saja Bahasa Arab, Suryani, Habshi, Nabti, dan bahasa-bahasa lainnya yang serumpun, berasal dari bahasa induk yang sama, yaitu bahasa semit klasik. ${ }^{26}$ Adanya fenomena unsur serapan dari bahasa lain, sebenanya sama sekali tidak mengganggu identitas suatu bahasa. al-Quran tetap saja dikatakan berBahasa Arab, meski ada beberapa istilah yang oleh para ahli sejarah bahasa dikatakan bukan sebagai asli dari Bahasa Arab. Masalahnya, lagi-lagi karena orang Arab saat di mana al-Quran diturunkan memang sudah menganggapnya bagian dari Bahasa Arab. walau para ahli sejarah bahasa menyatakan bahwa kata tersebut berasal dari unsur serapan dari bahasa lain.

Untuk menguatkan analisa di atas, ada baiknya dikutip pernyataan Quraish Shihab dalam bukunya Mukjizat al-Quran: "Tidak dapat disangkal bahwa ayatayat al-Quran tersusun dengan kosa kata Bahasa Arab, kecuali beberapa kata yang masuk dalam perbendaharaannya akibat akulturasi."27 Yaitu, pengaruh dari percampuran kebudayaan Arab dengan kebudayaan-kebudayaan lainnya, terutama sekali percampuran antara sesama bangsa yang masih berada dalam satu rumpun, yakni rumpun semit.

Di samping itu, perlu juga dicatat pernyataan W. Wontgomery Watt, dalam bukunya Bell's Introduction to the Qur'an, ${ }^{28}$ ungkapnya: "Pandangan beberapa cendekiawan muslim yang diwakili oleh al-Suyuti (w. 1505) dan 'Abd alRahman al-Tha'alabi (w. 1468), yang dengan penuh nalar menyatakan bahwa sebagai akibat hubungan orang-orang Arab dengan bangsa asing, berbagai kata bukan Arab masuk ke dalam Bahasa Arab, tetapi karena kata-kata ini sudah diarabkan, maka masih benar bahwa dikatakan al-Quran ditulis dalam Bahasa Arab. Ya'qub juga menyatakan telah ada ketetapan di kalangan ahli bahasa bahwa memang terdapat unsur serapan dari bahasa asing dalam alQuran. ${ }^{29}$ Ya'qub memetakan beberapa metode yang dilakukan dalam proses ta'rib atau yang disebut dengan manahij fi ta'rib al-alfaz yang biasa digunakan oleh masyarakat Arab ketika akan mengambil kata yang berasal dari bahasa 'ajam dan menjadikan kata tersebut sebagai bagian dari Bahasa Arab. Metode yang dimaksud adalah:

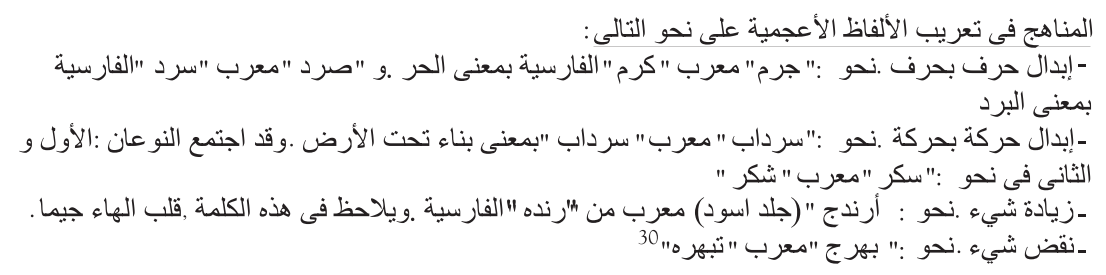


Berdasarkan uraian-uraian di atas, tidak berlebihan kiranya jika disimpulkan bahwa tidak ada satu pun bahasa di dunia ini yang tidak punya unsur serapan dari bahasa lain. Terlebih lagi jika bahasa-bahasa itu masih memiliki rumpun bahasa yang sama, seperti Bahasa Arab dengan bahasa-bahasa semit lainnya. Jadi, wajar, logis dan masuk akal bila dalam bahasa yang digunakan oleh orang Arab terdapat satu atau dua kosa kata yang merupakan serapan dari bahasa lain, bahkan ketika kosa kata tersebut menjadi bagian dari lafaz-lafaz yang digunakan al-Quran.

Pembahasan yang paling mudah dan terjangkau bagi pembaca berbahasa Inggris adalah karya Arthur Jeffery, ${ }^{31}$ melukiskan bagaimana usaha para cendikiawan muslim dalam menangani masalah serapan kata, Arthur mencatat sekitar 275 kata selain kata nama diri yang dianggap sebagai kosa kata asing dalam al-Quran. ${ }^{32}$ Berdasarkan hasil analisisnya terhadap buku-buku karya tokoh Islam, seperti al-Itqan fi Ulum al-Quran dan al-Muhadhdhab fima waqa'a fi al-Quran min al-Mu'arrab karya al-Suyuti, serta buku al-Mu'arrab karya alJawaliqi, dia mengklasifikasikan kosakata asing dalam al-Quran berdasarkan asal-usulnya, sebagai berikut, yaitu: a. Words borrowed from Ethiopic (للسان الحبشة), b. Words borrowed from Persian(اللغة الفارسية), C. Words borrowed from Greek(اللغة الرومية), d. Words borrowed from Indian(اللغة الهندية), e. Words borrowed from Syriac(اللغة الشريانية), f. Words borrowed from Hebrew(اللغة العبر انية), g. Words borrowed from Nabatiean(اللغة النبطية), h. Words borrowed from Coptic(اللغة القبطية), i. Words borrowed from Turkish(اللغة التركية), j. Words borrowed from Negro(اللغة الزنجية), k. Words borrowed from Berber(اللغة البربرية). Klasifikasi asal-usul bahasa yang dibuat oleh Arthur sebenarnya hanya copy paste dari apa yang telah dahulu dilakukan oleh tokoh-tokoh Islam, seperti alSuyuti dan al-Jawaliqi.

Sementara itu, Shahin, sebagaimana dikutip oleh Salman Harun dalam bukunya Mutiara al-Quran, juga telah meneliti kata-kata yang diduga berasal dari bahasa selain Arab berdasarkan informasi yang diberikan oleh Abu Hatim al-Razi di dalam al-Zinah, dan al-Suyuti di dalam al-Itqan. Ia menemukan empat kelompok kata yang dikatakan berasal dari bahasa bukan Arab, yaitu: (a). Kelompok bahasa-bahasa Semit; bahasa Ethiopia, Suryani, Ibrani, dan Nabti. (b). Kelompok bahasa-bahasa Indo-Eropa; Yunani dan bahasa Persi. (c). Kelompok bahasa-bahasa Hamit, bahasa Barbar dan bahasa Kopti. (d). Kelompok bahasa-bahasa Turanik, bahasa Turki dan bahasa-bahasa bukan Arab lain. ${ }^{33}$

Untuk mengidentifikasi keajaman suatu kata, para linguis Arab menerapkan 
beberapa prinsip yang dengan prinsip-prinsip tersebut keajaman suatu kata dapat diketahui. Prinsip-prinsip yang dimaksud adalah:

$$
\begin{aligned}
& \text { العلامات يعرف بها المعرب فى العربية : }
\end{aligned}
$$

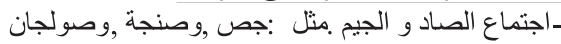

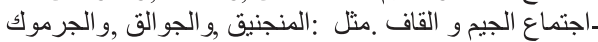

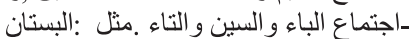

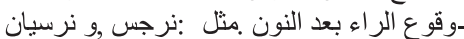

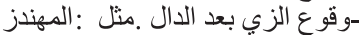

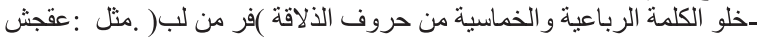

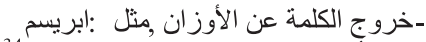

$$
\begin{aligned}
& \text { ـنص أنمة اللغة على ان اللفظ غير عربية } 34
\end{aligned}
$$

Al-Suyuti, selain memuat pendapatnya sendiri ia juga memuat pendapat Ibn al-Subki dan al-Khafiz Ibn Hajar yang mengumpulkan kosa kata bukan Arab yang digunakan al-Quran dalam bentuk syair berikut: ${ }^{35}$

1. Menurut Ibn al-Subki:

\begin{tabular}{|c|c|}
\hline رومُ وُطوبى وَسيجيَّلَ وكَافورُ & 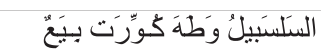 \\
\hline إِستَبرَقِ صَلَواتُ سُندُسْ طورُ & وَالزَنَجَبِيلُ وَمِشِكاةٌ سَر ادِقِّ مَع \\
\hline قُ" نُمَ دينارُ وَالقِسطاسُ مَشهورُ & كَذا قُر اطيس رَبَانِيِّهِ وَغَســا \\
\hline وَيُؤت كِفلِين مَذَّور" وَمَسطورُ & 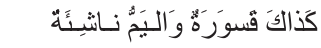 \\
\hline تَنْورُ فيما حَكى إِنُ دُرَيدٍ مِنهُ & للهُ مَقَاليدُ فِردَوسُ يُعَدُ كَذا \\
\hline
\end{tabular}

2. Menurut al-Khafiz Ibn Hajar:

\begin{tabular}{|c|c|}
\hline رى وَالأبٌُ تُمَّ الجبـتُ مَذَكَورُ & 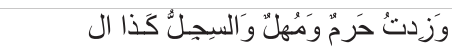 \\
\hline 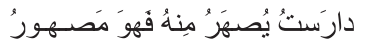 & 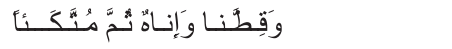 \\
\hline وَأوبِّي مَعهُ وَالطاغوتَ مَسطرورُ & 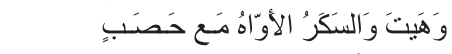 \\
\hline 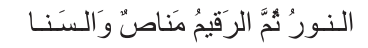 & صِر هُنَّ أصرَي وَغَيضَ الماءُ مَع وَزَرَ. \\
\hline
\end{tabular}

3. Menurut al-Suyuti:

\begin{tabular}{|c|c|}
\hline تٍٍَ ثُمَّ سينينَ شَطرَ الَيَيتِ مَشهورُ & وَزدتُ يِ وَالرَحَمَنُ مَعَ مَلكو \\
\hline جانْ أليمُ مَعَ القِنطار مَذَكورُ & 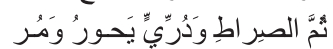 \\
\hline هُ وَالأر ائكِكُ وَالأكو ابُ مَأثنورُ & وَرَاعِنا طفقِا هُدنا إبلـعـي وَوَرَ \\
\hline هَوَنْ يَصَدّونَ وَالمَنَساهُ مَسطورُ & 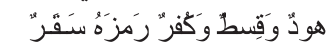 \\
\hline ريّونَ كَنز" وَسَجِّينٌ وَتَثَبِيرُ & 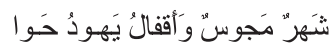 \\
\hline إلِّ وَمِن تَحتِها عَبَّدتَ وَالصـورُ & بَعبيرُ آزَرُ حـوبُ وَ \\
\hline 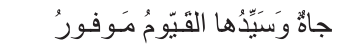 & 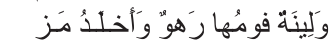 \\
\hline 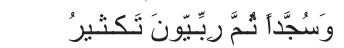 & 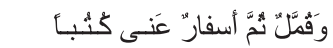 \\
\hline عَدنُ وَمَنفَطِرُ الأسباط مَذكَرُ & وُحِطَّة وَطوى وَالرسُ نونُ كَذا \\
\hline ما فاتَ مِن عَدَدِ الألفاظٍ مَحصورُ & مِسكَ أباريقُ ياقوتَ رَوَو ا فُهُنـا \\
\hline وَالآخِرَةَّلِمعاني الضِدِّ مقصــورُ & وَبَعضُهُهُ عَدَّ الأولى مَع بَطائيُهـا \\
\hline سينا أو ابِ وَالمرقومُ تَقصيرُ & وَمَا سُكوتِيَ عَن آن وَآنِيةٍ \\
\hline
\end{tabular}


Dari ketiga syair di atas dapat diketahui bahwa bentuk-bentuk ta'rib dalam al-Quran sebagaimana terungkap di atas dapat dijelaskan secara berurut sebagai berikut: ${ }^{36}$

a. Huruf Hamzah

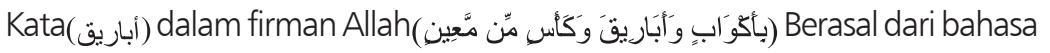

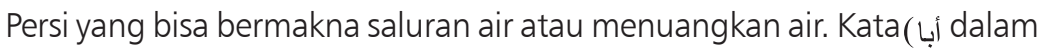
firman Allah(وَفَاكِهَة وَأبَّ), yang berarti alhissis (rumputan) dalam bahasa ahlu al-Maghrib. Kata(إبلعى) dalam firman Allah (يَا أرْضُ ابْلعِي مَاءكِّ) Ibnu Hatim dalam tafsirnya, sebagaimana dikutip oleh al-Suyuthi, menyatakan bahwa kata ibli'l Berasal dari bahasa Habsyi. Sementara Saikh bin Hayyan menyatakan berasal dari bahasa Hindi. Kata(أخلد) dalam ayat

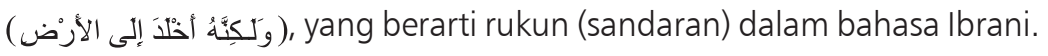

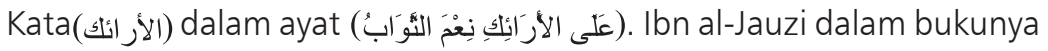
Funun al-Afnan, sebagaimana dikutip oleh al-Suyuti menyatakan itu adalah bahasa Habsi yang berarti dipan atau ranjang. Kata(ازر) dalam ayat

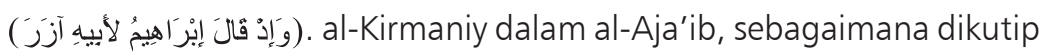
oleh al-Suyuthi menyatakan bahwa Azar dalam ayat di atas berasal dari bahasa Persi yang berarti Syaikh (orang yang sudah uzur). Kata (استبرق). Menurut Abu Hatim dan Abu Ubaid, sebagaimana dikutip oleh al-Suyuthi berpendapat bahwa kata tersebut berasal dari bahasa Persi.

Kemudian Kata (اسفار) al-Wasith dalam al-Irsyad menyatakan kata tersebut berasal dari bahasa Suryani, sementara al-Kirmaniy berpendapat bahwa kata tersebut berasal dari bahasa Nabti. Kata asfar, baik dalam bahasa Suryani ataupun nabti sama-sama berarti al-Kutub (kitab). Kata (اصرى). Abu al-Qasim dalam kitabnya Lughat al-Quran menyatakan kata tersebut berasal dari bahasa Nabti yang berarti 'ahdiy (perjanjian). Kata (اكو ), berasal dari bahasa Nabti yang berarti gelas atau cangkir. Kata (أليم) berasal dari bahas Ibrani. Kata (إلاب) baha baha nabti yang merupakan nama Allah. Kata (إناه) Menurut Abu Qasim dalam bukunya lughat al-Quran, kata tersebut berasal dari bahasa Barbar. Kata ( ان ) berasal dari bahasa Barbar. Kata (انية) dalam firman Allah(من عين انية) berasal dari

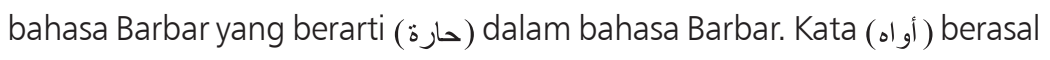
dari bahasa Habsyi. Kata (أو اب) berasal dari bahasa Habsyi yang bermakna 
(أوبى) Kata) berasal dari bahasa Habsy. Kata) (الوبى) dalam firman Allah (الجاهلية الأولى) dan (فلى العلى الأخرة) berasal dari bahasa Habsyi. Sebagaimana dinyatakan al-Zarkasyi dalam al-Burhan, di mana orang-orang Nabti menamakan al-akhirah dengan al-ula dan al-ula dengan alakhirah.

b. Huruf ba

Kata(بطائنها) dalam firman Allah(بطانتها من استبرق) berasal dari bahasa Qibti.

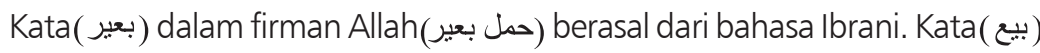
berasal dari bahasa Persi.

c. Huruf Ta

Kata(تنتير (ن) dalam firman Allah (وليتبروا ما علو ا تتبير ) berasal dari bahasa Nabti.

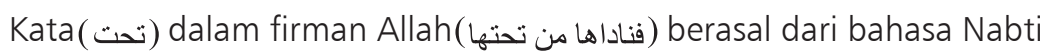
dan kata Kata(تنور) berasal dari bahasa Persi.

d. Huruf Jim yaitu kata (جبت) berasal dari bahasa Habsyi dan kata kata (İaaãã) berasal dari bahasa Persyi.

e. Huruf Ha

Kata (حرام) berasal dari bahasa Habsyi. Kata (حصب) berasal dari bahasa Zanjiy. Kata (حطة) berasal dari bahasa ahlu al-kitab yang tidak diketahui maknanya dalam Bahasa Arab. Kata (حوب) dalam firman Allah

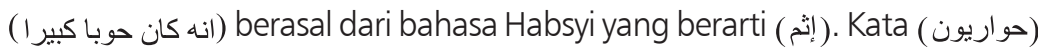
berasal dari bahasa Nabti.

f. Huruf Dal yaitu Kata (درست) berasal dari bahasa Ibrani. Kata (دري) berasal dari bahasa Habsyi. Kata (دينار) berasal dari bahasa Persi.

g. Huruf Ra

Kata (راعنا) adalah bahasa yang digunakan orang Yahudi. Kata(ربانيون) berasal dari bahasa Ibrani atau Suryani, pendapat ini sebagaimana dinyatakan oleh al-Jawaliqi. Kata (ربيون) berasal dari bahasa Ibrani. Kata

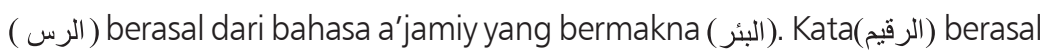

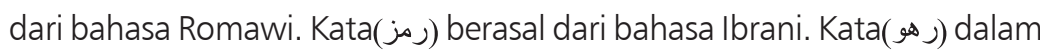
firman Allah (واترك البحر رهوا). Abu Qasim dalam bukunya Lughat al-Quran menyatakan bahwa kata tersebut berasal dari bahasa Nabti yang bermakna (سهلا) , sementara al-Wasiti menganggapnya berasal dari bahasa Suryani yang bermakna (ساكنا). Kata (الروم) berasal dari bahasa a'jami (asing), nama salah satu bangsa anak manusia.

h. Huruf Za, hanya ditemukan dalam kata(الزنجبيل) berasal dari bahasa Persi.

i. Huruf Sin 
Kata(سجدا) dalam firman Allah(و ادخلو الباب سجدا سجدا) berasal dari bahasa Suryani, Kata(السجل) berasal dari bahasa habsyi. Kata(الزبنجيل) Ada berbagai

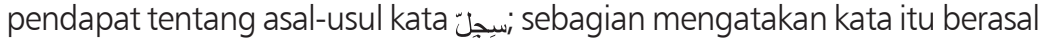
dari Abysinia dan berartialaki), Ibnu Jinni mengartikannya dengan surat dan menurutnya kata ini berasal dari bahasa Parsi, Khaffaji sepakat dengan pendapat yang mengatakan kata ini berasal dari Abysinia dan berarti surat. Sedang Arthur Jeffery menolak dua pendapat tersebut dan menyatakan bahwa kata ini bukan berasal dari Abysinia dan juga bukan dari Persi, melainkan dari bahasa Yunani yang sepadan dengan kata Latin "sigillum". Kata (سجين). Abu Hatim tidak member komentar banyak perihal kata ini, hanya mengomentarinya dengan ungkapan (انه غير عربية). Kata(سر ادق) berasal dari bahasa Persi. Kata(سفرة) berasal dari bahasa Nabti. Kata(سكر) berasal dari bahasa Habsyi. Kata(سرىم) adalah nama a'jamiy. Kata) berasal dari bahasa Persi. Kata)(سلسبيل) dalam firman Allah) berasal dari bahasa Qibti. Kata(سو الفبا سيدها لدى الباب) berasal dari bahasa Habsyi dan kata(سينا (سياب) berasal dari bahasa Nabti.

j. Huruf Shin yaitu kata(شطر) dalam firman Allah(شطر المسجد الحرام) berasal dari, bahasa Habsyi, dan kata(شهر) berasal dari bahasa Suryani.

k. Huruf Sad yaitu kata(الصراط) berasal dari bahasa Romawi yang berarti(الطريق), dan kata(صر هن) berasal dari bahasa Nabti.

I. Huruf Ta yaitu kata(طه) berasal dari bahasa Habsyi, kata(الطاغوت) berasal dari bahasa Habsyi yang berarti(كاهن), kata(طفقا) berasal dari bahasa Romawi, kata)berasal dari bahasa Habsyi, kata(طوبى) berasal dari bahasa Suryani yang berarti(الجبل), dan kata(طوى) berasal dari bahasa Ibrani yang berarti (رجل)

m. Huruf 'Ain yaitu kata(عبدت) dalam firman Allah( رجبل) (ان عبدت بنى اسر ائيل) berasal dari bahasa nabti yang berarti(نتلت), kata(عدن) berasal dari bahasa Suryani dan kata( العرم) dalam firman Allah) (سيل العرم) berasal dari bahasa Habsyi.

n. Huruf Ghain yaitu kata(غساق) berasal dari bahasa Turki, dan kata(غيض) berasal dari bahasa Habsyi.

O. Huruf Fa yaitu kata(الفردوس) berasal dari bahasa Romawi yang

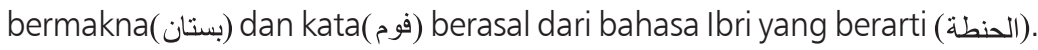

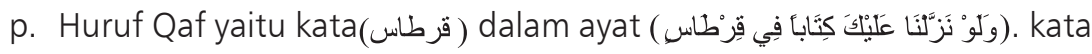
ini bukan Bahasa Arab asli dan berasal dari kata "charta" dalam bahasa Yunani sedang dalam bahasa Abysinia adalah kartas. Sementara itu, alSuyuthi hanya mengomentarinya dengan pernyataan ان القرطاس غير عربى". 
Kata(القسط) dan (القسطاس) aslinya berasal dari bahasa Romawi, kata( قسورة) berasal dari bahasa Habsyi, kata(قطنام) berasal dari bahasa Nabti yang berarti(كتابنا), kata(القمل)aslinya adalah bahasa Persi. Kata( (القل) berarti(الدبا), dalam bahasa Ibri atau Suryani, sementara Abu Umar, ketika ditanya terkait kosa-kata tersebut, menyatakan ketidak tahuannya tentang asal-usul kosakata tersebut. ${ }^{37}$ Kata( قنطار), ada banyak pendapat terkait asal-usul kata tersebut. Setidaknya, ada empat pandangan berbeda sebagaimana dikutip oleh al-Suyuti; Tha'âlabi menyatakan kata tersebut aslinya adalah Romawi, al-Khalil mengatakan berasal dari Suryani, ibn Qutaibah menyatakan berasal dari Afrika, sementara yang lain menyatakan berasal dari bahasa Barbar. ${ }^{38}$ Adapun kata(القيم) berasal dari bahasa Suryani.

q. Huruf Kaf yaitu kata(كافور) berasal dari bahasa Persi. Terkait kata(كافور)), Salman Harun memberi catatan khusus dengan menyatakan bahwa kata tersebut sebenarnya bukanlah berasal dari bahasa Persia akan tetapi berasal dari kosa-kata bahasa Indonesia, yaitu dari kata kapur barus yang diserap oleh bahasa-bahasa lain di dunia, yang kemudian diserap ke dalam Bahasa Arab. ${ }^{39}$ Kata(كفر) dalam ayat(كفر عنهم سيئاته) berasal dari bahasa Ibrani. Di samping kata tersebut, kata(كفلين) berasal dari bahasa Habsyi, kata(كتر) (كنر) berasal dari bahasa Persi, kata)(كورت)dalam ayat(إذا الشمس كورت) berasal dari bahasa Persi.

r. Huruf Mim yaitu kata(منكئا) aslinya adalah Habsyi, kata)(مرقوم) dalam firman Allah (كتاب مرقوم) berasal dari bahasa Ibri, kata(مزجاة) berasal dari bahasa Qibti, kata(مسك) berasal dari bahasa Persi, kata(مشكاب) berasal dari bahasa Habsyi, kata(مقاليد) dalam ayat) (له مقاليد السموات الأرض) berasal dari bahasa

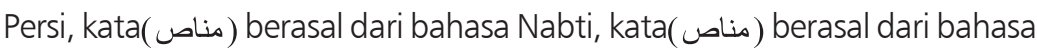
Nabti, kata(منساة) berasal dari bahasa Habsyi, kata(منفر) berasal dari bahasa Habsyi dan kata(المهل) yang berasal dari bahasa Barbar.

S. Huruf Nun yaitu kata(ناشئنة) dalam firman Allah(إن ناشئة الليل) berasal dari bahasa Habsyi.

t. Huruf Ha, yaitu kata(هدنا) berasal dari bahasa Ibrani, kata(هون) dalam ayat(هو عباد الرحمن الذين يمشون على الأرض هونا berasal dari bahasa Suryani dan

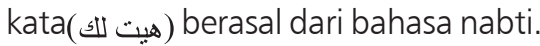

u. Huruf Waw yaitu kata) berasal dari bahasa Nabti, kata(ورودة) dalam firman Allah(فاءذا انشقت السماء فكانت وردة), tidak ada keterangan jelas terkait asal-usul kata ini tapi ada kesepakatan untuk menyatakan bahwa ia bukan Bahasa Arab asli (ليس بعربى), dan kata(وزر) berasal dari bahasa Nabti. 
v. Huruf Ya, yaitu kata(ياقوت) berasal dari bahasa Persi, kata(يحور) dalam ayat (انهظن ان لن يحور berasal dari bahasa Persi, kata(بس) berasal dari bahasa Habsyi, kata(يصدون) berasal dari bahasa Habsyi.

Berangkat dari uraian di atas terlihat jelas bahwa terdapat kata-kata yang berasal dari bahasa asing di dalam al-Quran. Sebaliknya pendapat yang meyakini bahwa al-Quran tidak mengandung kata-kata yang berasal dari bahasa asing sebagaimana dinyatakan oleh Shahin adalah tidak benar karena tidak didukung oleh fakta-fakta yang ada.

\section{Pandangan Orientalis terhadap Bahasa al-Quran}

Orientalis adalah kata majemuk yang terdiri dari kata oriental dan isme. Menurut etimologi kata oriental berasal dari bahasa Romawi yang asal katanya orient, yang berarti "timur". ${ }^{40}$ Secara terminologi orientalis dapat dipahami sebagai suatu paham, ajaran atau aliran yang membahas tentang sesuatu yang berkaitan dengan Negara-negara dan bangsa-bangsa timur dengan segenap aspeknya, baik yang berkenaan dengan agama dan ajarannya, sejarah, geografis, bahasa dan sastra. Sementara al-Tunji memberikan pengertian yaitu ilmuan Barat yang memfokuskan kajiannya terhadap bahasa Timur atau sastranya. ${ }^{41}$ Banyak di antara orientalis yang memfokuskan kajian dalam bidang Bahasa Arab dan al-Quran, terhadap Bahasa Arab ilmuwan Barat Eropa berpendapat bahwa huruf-huruf Arab dan Eropa tumbuh dan berkembang dari satu asal yaitu dari bahasa finiqiyyah klasik yang telah ada sebelum masehi. $^{42}$

Tokoh Kristen di Barat yang mensibukkan diri untuk mempelajari ilmuilmu keislaman di Andalusia, dan hal ini merupakan awal kejayaan orientalis, pada awalnya mereka bergerak untuk kejayaan agama mereka, syair-syair Kristen, baik protestan maupun katolik dengan tujuan untuk memperluas wawasan keagamaan dan buku-buku yang menjadi dasar bagi mereka dalam mengembangkan ajaran agama Kristen. Dengan demikian mereka memusatkan studi Bahasa Arab dan studi tentang Islam, dengan berkembangnya zaman, studi mereka meluas kepada agama, budaya, dan bahasa-bahasa yang ada di Timur. ${ }^{43}$

Adapun pendapat orientalis terhadap bahasa al-Quran ialah dapat dilihat dari beberapa statemen mereka, Noldeke misalkan mengatakan tidak dapat diterima secara ilmiah dan tidak masuk akal kalau dikatakan Muhammad telah memakai di dalam al-Quran bahasa yang sama sekali berbeda dengan 
bahasa yang sedang berkembang pada saat itu. ${ }^{44}$ Dalam hal ini dia mengkritisi kemukjizatan al-Quran dari segi gramatika bahasa al-Quran.

Sementara itu Arthur mengklaim bahwa tafsir al-Quran yang ada sekarang tidak kritis dan belum memuaskan karena tidak memuat pengaruh bahasa asing. Dalam kajian Arthur dia menyimpulkan bahwa al-Quran terpengaruh berbagai bahasa asing, seperti Ethopia, Aramaik, Ibrani, Yunani kuno, Persia dan bahasa lainnya. Jadi istilah-istilah dan kosa kata yang ada di dalam alQuran mengambil dari istilah-istilah Yahudi, Nasrani dan lainnya. ${ }^{45}$ Jika pengaruh kosa kata asing di dalam al-Quran bisa dieksplorasi, Arthur berharap kamus al-Quran yang memuat sumber-sumber filologi, efigrafi dan analisis teks Arab akan bisa diwujudkan. ${ }^{46}$

Dalam mengkritisi bahasa al-Quran para orientalis menggunakan kajian dengan pendekatan filologi, ${ }^{47}$ yaitu sebuah kajian yang digunakan untuk mempertanyakan orisinalitas sebuah teks, adapun ciri-ciri kajian Filologi ini adalah mempertanyakan berbagai hal: a. Dari mana datangnya teks, b. Bagaimana cara memperoleh teks, c. Bagaimana autensitas, d. Sarana dan Prasarana apa yang digunakan dalam penulisan teks, e. Aslinya teks itu berbahasa apa dan dialek apa, f. Apa hubungan penutur dengan penulis teks, g. Apakah seorang penutur semasa (mu'asarah) dengan penulis, h. Apakah penutur dengan penulis berjumpa, i. Kalau teks itu ditranskrip siapa yang mentranskrip. ${ }^{48}$

Mempertanyakan orisisnalitas al-Quran dengan pendekatan Filologi ada dua kemungkinan yang bisa terjadi, pertama orisinalitas al-Quran ditemukan ada masalah, dengan mengungkapkan data dan fakta yang memang tidak seragam dalam penulisan al-Quran sejak awal, karena penutur untuk ditulis adalah Muhammad, penulis sahabat, sementara sumber asli dari Allah, Kedua pendekatan filologi mempunyai keterbatasan dalam dirinya sendiri karena hanya mengandalkan analisis teks, dan teks dalam konotasi tulisan terkait dengan sarana dan prasarana. Contohnya, dalam manuskrip Ibn Mas'ud tiga surat terakhir karena populernya tidak dimuat lagi, (al-Ikhlas, al-Falaq dan alNas), atas dasar ini pulalah yang digunakan Goldhizer sehingga dia menolak ketiga surat itu sebagai bagian dari al-Quran. ${ }^{49}$

Robert Morey menyatakan bahwa masuknya bahasa asing dalam al-Quran dikatakan "kecolongan"50 apalagi jika alasan tersebut dijadikan dasar untuk menyatakan bahwa ajaran al-Quran dari bangsa asing. Bahasa asing yang masuk dalam bahasa al-Quran adalah bahasa asing yang sudah diadopsi Bahasa Arab. Beradasarkan pemaparan di atas, dapat dipahami bahwa keberadaan kosa kata dan istilah dari bahasa lain selain Bahasa Arab dalam al-Quran menurut 
orientalis merupakan kelemahan al-Quran yang hanya dapat mengadopsi halhal yang sudah ada sebelumnya.

\section{Pendapat Ulama terkait Persoalan Bargaining/Ta'rib dalam al-Quran}

Sejak dahulu para ulama ternyata sudah banyak mendiskusikan hal ini. Setidaknya ada tiga pendapat yang berkembang dengan sikap berbeda terkait persoalan kosa-kata serapan asing (ta'rib) dalam al-Quran. ${ }^{51}$ Sementara itu, adanya kata-kata asing dalam pengertian bahasa non Arab yang diarabkan oleh masyarakat Arab kemudian dipakai oleh al-Quran, ulama berbeda pendapat. ${ }^{52}$ Pendapat pertama mengatakan bahwa dalam al-Quran tidak terdapat bahasa non Bahasa Arab, dengan argumentasi bahwa al-Quran dijadikan Allah sebagai kitab mukjizat dan bukti risalah Nabi Muhammad SAW, sebagai tantangan bagi orang Arab (untuk membuat serupa al-Quran); apabila dalam al-Quran terdapat bahasa selain Bahasa Arab, maka tujuan penurunan al-Quran ini tidak ada manfaatnya (lam takun lahu faidah), karena Bahasa Arab dipandang lemah untuk menjadi media bahasa al-Quran. Pendapat ini merupakan pendapat jumhur ulama seperti al-Syafii, Abu Ubaidah, Muhammad Ibnu Jarir al-Thabari, dan Abu Bakr Ibn Thayyib. ${ }^{53}$ Sementara pendapat kedua adalah yang membenarkan adanya bahasa selain Bahasa Arab dalam al-Quran, sebagaimana pendapat Ibnu Abbas dan Ikrimah; bahkan Imam Abu Hanifah membolehkan membaca al-Quran dengan bahasa Persia. ${ }^{54}$ Untuk lebih jelasnya bagaimana pendapat ahli tentang keberadaan kosa kata selain Bahasa Arab di dalam al-Quran berikut diungkapkan pendapat para ahli:

\section{1. al-Quran Seluruhnya Berbahasa Arab}

Pendapat pertama mengatakan al-Quran 100\% berBahasa Arab, tidak ada unsur serapan dari bahasa lain. Hal itu karena di dalam al-Quran disebutkan secara tegas dan lebih dari satu kali tentang hal itu. maka tidak pada tempatnya kalau dikatakan bahwa di dalam al-Quran ada bahasa selain Bahasa Arab. Di antara ulama yang berpendapat seperti ini adalah, al-Imam al-Shafi'i, ibn Jarir al-Tabari, Abu 'Ubaidah, al-Qadi Abu Bakr, dan Ibn Faris. ${ }^{55}$ Imam al-Shafi'i mengatakan, "Di antara point penting dalam ilmu al-Quran adalah bahwa seluruh al-Quran ini diturunkan dalam Bahasa Arab. Memang ada sementara kalangan yang berpendapat bahwa ada serapan bahasa lain selain Bahasa Arab di dalam al-Quran, namun hal itu bertentangan dengan keterangan di 
dalam al-Quran sendiri."

Imam al-Shafi'i menambahkan kalau ada ahli bahasa yang mengatakan di dalam al-Quran ada lafal selain Arab, sebenarnya bukan demikian kejadiannya, yang benar adalah bahwa ada sebagian orang Arab yang tidak tahu kalau kata itu merupakan bahasa mereka, lantas dia beranggapan lafal itu bukan Bahasa Arab. Padahal Bahasa Arab sangat banyak kosa katanya dan sangat luas cakupannya. Atau apa yang dianggap ahli bahasa sebagai lafal bukan Bahasa Arab, sebenarnya secara kebetulan memang ada di dalam bahasa lain. Namun lafal itu tetap ada dalam Bahasa Arab. Dan kesamaa lafal pada dua bahasa yang berbeda bukan hal yang aneh atau mustahil.

Kalau ada yang mengatakan bahwa boleh al-Quran mengandung bahasa lain karena memang diturunkan bukan hanya untuk orang Arab, al-Shafi'i menjawab sebaliknya. Justru diturunkannya al-Quran dalam Bahasa Arab meski untuk semua manusia, tujuannya agar semua umat manusia belajar Bahasa Arab, bukan al-Quran yang harus berisi berbagai bahasa, tetapi berbagai bangsa itulah yang harus belajar Bahasa Arab sebagai bahasa yang digunakan oleh alQuran. Imam al-Shafi'i mengatakan bahwa Allah menegaskan bahwa kitabNya itu berBahasa Arab, di semua ayat yang dibacakannya. Bahkan Allah menafikan semua bahasa yang bukan Arab di dalam kitab suci-Nya.

Ibn Faris mengatakan tidak ada di dalam al-Quran lafaz selain Bahasa Arab. Sebab seandainya ada pastilah akan ada tuduhan bahwa Bahasa Arab terlalu lemah dan tidak mampu menampung pesan yang banyak, sampai harus menggunakan bahasa lain untuk membantunya. ${ }^{56}$ Dan tuduhan itu ternyata sudah dilemparkan oleh para orientalis serta sudah dijadikan jenjang untuk sampai kepada tuduhan kelemahan al-Quran.

Ulama di zaman sekarang yang berpendapat seperti ini antara lain adalah Shaikh Ahmad Shakir, muhaqqiq kitab al-Mu'arrab Min al-Kalam al A'jami yang ditulis oleh al-Jawaliq. la mengatakan bahwa anggapan adanya lafaz selain Arab dalam al-Quran sebenarnya hanyalah perkiraan saja. Hal yang sebenarnya terjadi adalah bahwa para ahli bahasa itu pun tidak mengetahui asal kata-kata tersebut. ${ }^{57}$ Padahal harus diketahui bahwa bangsa Arab adalah bangsa yang sudah ada sejak zaman dahulu sebelum sejarah ditulis. Jauh sebelum zaman Ibrahim dan Ismail. Sudah ada sebelum masa keberadaan bahasa Kaldaniyah, bahasa Ibrani, bahasa Suryaniyah dan bahasa Persia. Jadi tidak ada istilah bahasa-bahasa yang lebih muda diserap ke dalam Bahasa Arab, yang ada sebenarnya lafal-lafal itu asli dari Bahasa Arab sejak dahulu, kemudian diserap oleh bahasa lain yang lebih muda, lalu datanglah orang- 
orang kemudian dan beranggapan bahwa lafal itu serapan dari bahasa lain ke Bahasa Arab.

\section{2. al-Quran Memuat Kata-Kata Selain Bahasa Arab}

Di antara ahli yang berpendapat seperti ini adalah al-Khuwayyi, ibn alNaqib dan Imam al-Shaukani. Diriwayatkan dari ibn 'Abbas, Mujahid, ibn 'Ikrimah, Ata' dan lainnya dari ahli ilmu bahwa mereka telah menyatakan terdapat banyak bahasa ajam (non-Arab) di dalam al-Quran. ${ }^{58}$ Di antaranya lafal: taha, al-yammu, al-tur, al-rabbaniyyun, semuanya adalah bahasa Suryaniyah. Lafal mishkat serta qiflaini berasal dari serapan bahasa Romawi. Sedangkan lafal sirat, qirtas, firdaus dan sejenisnya berasal dari serapan bahasa Habashah. Para ahli nahw (nuhat) telah sepakat bahwa di dalam al-Quran banyak lafal yang mamnu' min al-sarf, baik karena merupakan al-'alam (nama) atau karena kenon-araban ('ajam), seperti lafal Ibrahim. Jika demikian, maka tidak ada alasan untuk menolak adanya lafal yang bukan Bahasa Arab di dalam al-Quran. ${ }^{59}$

Para ahli yang mengikuti pendapat ini beranggapan bahwa di antara hikmah adanya lafal non-Arab di dalam al-Quran adalah bahwa al-Quran mencakup ilmu terdahulu dan kemudian, serta mengabarkan segala sesuatu. Di dalamnya harus ada petunjuk kepada bermacam bahasa dan ragam lidah manusia, agar cakupannya menjadi sempurna, untuk itu dipilihlah dari berbagai macam bahasa tentang beberapa kata yang paling baik, mudah serta paling banyak dilafazkan oleh orang Arab. Ibn al-Naqib mengatakan karakteristik al-Quran adalah diturunkan dengan bahasa kaum yang memang kepada mereka alQuran ini diturunkan. Dan al-Quran memang diturunkan bukan hanya untuk orang Arab saja, tetapi untuk seluruh manusia. Dengan demikian tidak ada salahnya kalau di dalam al-Quran ada bahasa selain Bahasa Arab, seperti bahasa Romawi, Persia, Habasyah dan lainnya. ${ }^{60}$

Di antara ulama zaman kontemporer yang berpendapat bahwa di dalam al-Quran ada bahasa selain Bahasa Arab adalah Ramadan Abduttawwab dan Muhammad al-Sayyid 'Ali al-Balasi. Ramadan 'Abd al-Thawwâb telah menuliskan pendapatnya dengan salah satu ungkapannya "merupakan sebuah kesalahan mengingkari adanya unsur serapan bahasa asing di dalam Bahasa Arab fushah dan juga di dalam al-Quran". ${ }^{61}$ Muhammad al-Sayyid 'Ali al-Balasi dalam kritiknya terhadap kitab Al-Mudhdhab mengatakan bahwa para ulama telah sepakat mengatakan adanya kalimat 'ajam di dalam al-Quran, yang telah 
diarabkan oleh bangsa Arab sebelumnya, sehingga biar bagaimana pun tidak ada masalah bila kalimat yang asalnya bukan Arab terdapat di dalam al-Quran.

\section{Pendapat Pertengahan (al-Mu'tadil)}

Pendapat ketiga memandang bahwa hujjah yang mewakili pendapat pertama dan kedua sama-sama kuat, tidak bisa dipatahkan begitu saja. Jadi pendapat ketiga ini agaknya ingin mengkompromikan kedua pendapat yang saling berbeda. Di antaranya Abu 'Ubaid bin Qasim bin Salam, dia pernah menyatakan bahwa meski suatu lafaz awalnya dianggap bukan dari Bahasa Arab, namun kemudian berubah menjadi Bahasa Arab sehingga ketika alQuran turun lafaz itu sudah dikenal oleh bangsa Arab dan sudah dianggap menjadi bagian dari Bahasa Arab.

Dengan demikian kedua pendapat itu tidak salah dan tidak bertentangan secara hakikatnya. Ahli yang mengatakan bahwa lafaz itu bukan Bahasa Arab tidak bisa disalahkan karena mereka melihat dari asal muasal sejarah lafaz itu yang memang bukan Arab, tetapi yang mengatakan bahwa lafaz itu adalah Bahasa Arab juga benar, sebab pada saat al-Quran diturunkan lafaz itu sudah menjadi bagian dari Bahasa Arab. ${ }^{62}$ Pendapat ketiga ini prinsipnya tidak menyalahkan pendapat pertama atau kedua, tetapi menggabungkan semua hujjah untuk menjadi kesimpulan yang bisa disepakati bersama.

\section{PENUTUP}

Dari uraian-uraian di atas dapat diketahui dengan jelas jawaban dari permasalahan penulisan yang dijelaskan sebelumnya. Pertama, tentang keberadaan kata serapan di dalam al-Quran dapat terjawab dari pendapat kedua dan ketiga. Akan tetapi adanya arabisasi bukan untuk memperlemah bahasa al-Quran, sebaliknya adanya fenomena serapan kata justru menjadi salah satu karakteristik dan kelebihan al-Quran. Kemudian pertayaan kedua, bagaimana pandangan orientalis terhadap kosa kata asing dalam al-Quran, hal ini dapat dijawab bahwa mereka berpendapat fenomena tersebut merupakan kecolongan, dan ketidakkereatifan Islam yang hanya dapat memadukan hal-hal yang lama.

Ketiga adalah bagaimana pendapat para ulama mengenai ta'rib dalam alQuran? Dalam Masalah ini terdapat tiga pendapat para ulama, yang pertama: menolak keberadan serapan kata di dalam al-Quran. Mereka berpendapat bahwa al-Quran semuanya berBahasa Arab. Di antara ulama yang berpendapat 
seperti ini adalah Imam al-Shafi'i, ibn Jarir al-Tabari, Abu 'Ubaidah, al-Qadi Abu Bakr dan Ibn Faris. Kedua: menyatakan di dalam al-Quran terdapat kosa kata selain Bahasa Arab. Dengan alasan di dalam al-Quran terdapat lafaz yang mamnu' min al-sarf, baik karena merupakan al-'alam atau karena 'ajam. Di antara ulama yang berpendapat seperti ini adalah al-Khuwayyi, ibn al-Naqib, Ramadan Abduttawwab, Muhammad al-Sayyid 'Ali Al-Balasi. Ketiga: pertengahan, Pendapat ketiga ini merupakan pendapat yang mewakili pendapat pertama dan kedua. Di antara tokohnya adalah Abu 'Ubaid bin Qasim bin Salam, ia berpendapat bahwa meski suatu lafaz awalnya dianggap bukan dari Bahasa Arab, namun kemudian berubah menjadi Bahasa Arab ketika al-Quran diturunkan Tuhan.

\section{CATATAN AKHIR}

1 Sepuluh ayat yang penulis maksud ialah QS: Yusuf ayat 2, QS: al-Ra'du ayat 39, QS: al-Nahl ayat 103, QS: Thaha ayat ayat 113, QS: al-Shu'ara, ayat 195, QS: al-Zumar ayat 28, QS: Fussilat ayat 44, QS: al-Syura ayat 7, QS: al-Zukhruf ayat 3, dan QS: al-Ahqaf ayat 12.

2 Salman Harun, Mutiara al-Quran, Aktualisasi Pesan Al-Quran dalam Kehidupan (Jakarta: Kaldera, 1999), Cet., Ke-3, h. 162. Baca juga 'Abd al-Faris Salim, Tarikh al'Arab Qabl al-Islam (al-Iskandariyyah, T.tp, tt), h. 45.

3 Einar Haugen, Billingualism, Language Contact, and Immigrant Languages in the United States (The Hague: Mouton, 1956), h. 198.

4 Uriel Weinreich, Languages in Contact: Finding and Problems (The Hague: Mouton, 1953), h. 5.

5 Amil Badi' Ya'qub, Figh al-Lughah al-Arabiyyah wa Khasaisuha (Beirut: Dar alThaqafat al-Islamiyyah, 1998), h. 215.

6 http://jamal-alfath.blogspot.com//tarib.html.. di akses pada tanggal 22 April 2014

7 J. Gonda, Sanskrit in Indonesia (New Delhi: International Academy of India Culture, 1973), cet, Ke-2, h. 26.

8 Ramadan 'Abduttawwab, Fusull fi Figh al-Lughah al-Arabiyyah (Kairo: Maktabah al-Khaniji, tt), h. 358. Baca juga Yunus Ali al-Muhdar dan Bey Arifin, Sejarah Kesustraan Arab (Surabaya: PT. Bina Ilmu, 1938), h. 17-18.

9 Abd al-Wahid Wafi, Fiqh al-Lughah (Kairo: Dar Nahdah Misr li al-Tab'i wa alNasri, 1945), h. 200.

10 Khalid Muflih 'Isa, al-Lughah al-Arabiyah baina al-Fushah wa al-Amiyah (Dar alJamahiriyyah li al-Nashri wa al-I'lan, 1987), h. 59. Lihat juga pernyataan Ramadan 'Abduttawwab dalam Fusul fi Fiqh al-Lughah, h. 358. Lihat juga Muhammad al-Mubarak, Figh al-Lughah al-Arabiyyah wa Khasaisuha (Damaskus: Dar al-Fikr, 1960), h. 290-301.

11 Lihat misalnya tantangan (bertahap) al-Quran untuk terhadap orang-orang 
kafir untuk mendatangkan satu buah kitab seperti al-Quran (QS. Al-Thur: 33 34), sepuluh surat al-Quran (QS. Hud: 13-14) dan atau satu buah surat saja (QS. Al-Baqarah: 23-24). Lebih jauh tentang kemukizatan al-Quran, lihat Abd al-Ghaniy Muhammad Said Barkah, al-l'jaz al-Qurani: Wujuhu wa Asraruhu, (Kairo: Maktabat Wahbat, 1989).

12 Muhammad Abdullah Darraz, Al-Nab al-'Azhim, (Kuwait: Dar al-Qalam, 1974), h. 112. Senada dengan itu, Muhammad Arkoun menyatakan tentang keluasan makna bahasa al-Quran yang menurutnya memberikan kemungkinankemungkinan arti yang tak terbatas. M. Quraish Shihab, Membumikan Al-Quran: Fungsi dan Peran Wahyu dalam Kehidupan Masyarakat (Bandung: Mizan, 1996), h. 72 .

13 Taufik Adnan Amal, Rekonstruksi Sejarah al-Quran (Yogyakarta: FkBA, 2001), h. 12.

14 Taufik Adnan Amal, Rekonstruksi Sejarah al-Quran, (Yogyakarta: FkBA, 2001), h. 12 .

15 Nurcholish Madjid, Islam Doktrin dan Peradaban: Sebuah Telaah Kritis tentang Masalah Keimanan, Kemanusiaan, dan Kemodernan (Jakarta: Paramadina, 1995), h. 76-77. Keterangan yang dibuat oleh Ismail al-Faruqi tentang kepercayaan orang-orang Arab pra Islam bahwa Allah mempunyai anak-anak perempuan itu juga dengan jelas diisyaratkan oleh al-Quran dalam QS. 37: 149 dan QS. 52: 39. Sementra keterangan tentang berhala kaum musyrk Arab yang paling terkenal, yaitu Allat, al-Uzza dan al-Manat memang disebutkan dalam al-Quran dipercayai oleh orang-orang Arab jahiliyah sebagai anak-anak perempuan Tuhan terdapat pada QS. 53: 19-22.

16 Jalaluddin al-Suyuthiy, al-Itqan fi 'Ulum al-Quran (Beirut: Dar al-Fikr,t.th), h. 121-134.

17 Masnal Zajuli, al-Ishtirak fi al-Lughah al-Arabiyyah (Padang: Hayfa Press, 2008), h. 17 .

18 Amil Badi' Ya'qub, Fiqh al-Lughah al-Arabiyyah wa Khasâisuhâ, h. 113.

19 M. Qurais Shihab, Mukjizat al-Quran, h. 90.

20 Abu al-Fath 'Uthman Ibn Jinni, editor Ibrahim Mustafa dan 'Abdullah Amin, al-Munsif (Kairo: Matba'ah al-Babi al-Hilb, 1954), lihat juga Abu al-Fath 'Uthmam Ibn Jinni, editor Muhammad 'Ali al-Najjar, al-Khasais (Kairo: alHay'ah al-Misriyah al-'Ammah li al-Kitab, 1983 M), h. 231.

21 Mushthafa Shadiq al-Rafii, Tarikh Adab al-Arab (Kairo: Maktabat al-Iman, 1998), h. 71 .

22 Mushthafa Shadiq al-Rafii, Tarikh Adab al-Arab (Kairo: Maktabat al-Iman, 1998), h. 72 .

23 Kajian cukup komprehensif tentang konsep sab'atu ahruf ini dilakukan oleh Syaban Muhammad Ismail, Ma' al-Quran al-Karim, (Kairo: Dar al-Ittihad alArabiy li al-Thibaat, 1978), h. 267-390.

24 Hasanuddin AF, Anatomi al-Quran: Perbedaan Qiraat dan Pengaruhnya terhadap Istinbath Hukum dalam al-Quran (Jakarta: PT RajaGrafindo Persada, 1995), h. 99. 

60.

27 M. Quraish Syihab, Mukjizat al-Quran, h. 89.

28 W. Wontgomery Watt, Richard Bell: Pengantar Qur'an, Penerjamah: Lilian D. Tedjasudhana, Judul asli: Bell's Introduction to the Qur'an (Jakarta: INIS, 1998), h. 74 .

29 Amil Badi' Ya'qub, Fiqh al-Lughah al-Arabiyyah wa Khasaisuha, h. 219.

30 Amil Badi' Ya'qub, Fiqhu al-Lughah al-Arabiyyah wa Khasâisuhâ, h. 217.

31 Arthur Jeffery adalah seorang orientalis yang memperoleh profesornya di bidang semitic (bahasa-bahasa semit). Ia banyak menulis tentang al-Quran, di antara karyanya di bidang ini adalah: The Quran as a scripture (Quran sebagai kitab Injil), the textual history of the Quran (textual sejarah Quran); the orthography of the Samarqad codex (ortografi Samarqad Naskah kuno); Materials for the history of the text of the Quran (Material untuk sejarah teks Quran), and The Foreign vocabulary of the Quran (kosa kata asing dalam al-Quran).

32 Arthur Jeffery, Foreign Vocabulary of the Quran (Oriental institute, 1938), h. 13.

33 Salman Harun, Mutiara al-Quran, h. 163-166.

34 Ramadan 'Abduttawwab, Fusul fi Fiqh al-Lughah, h. 363. Bandingkan dengan Amil Badi' Ya'qub, Figh al-Lughah al-'Arabiyyah wa Khasaisuha, h. 218.

35 Jalaluddin 'Abdurrahman al-Suyuti, al-Itqan fi 'Ulum al-Quran (Beirut: Majma' al-Mulk, 1426 H), h. 200-201.

36 Jalaluddin 'Abdurrahman al-Suyuti, al-Muhadhdhabu fima Waqa'a fi al-Quran min al-Mu'arrab, (Beirut: Dar al-Fikr, 1987), h. 5-25.

37 Komentar Abu 'Umar, lengkapnya adalah (áÇ ÇƯÑÝå Ýi âÛÉ ÇîI ãä ÇáÚÑÈ). Baca al-Suyuti dalam al-Muhadhdhabu fima waqa'a fi al-Quran min al-Mu'arrab, 19.

38 Al-Suyuti, "al-Itqan fi 'Ulum al-Quran ", h. 199. Lihat juga Al-Suyuti, dalam alMuhadhdhab fima waqa'a fi al-Quran min al-Mu'arrab, h. 19.

39 Argumen yang dikemukakan Salman Harun adalah: Kapur barus, yang setelah diserap ke dalam Bahasa Arab menjadi (ßÇÝæÑ) merupakan komiditi dagang internasional semenjak abad ke-2 Masehi. Kapur barus hanya dihasilkan di pantai Barat Sumatera dengan kota Barus sebagai pelabuhannya. Berdasarkan kapur barus sebagai komoditi dagang internasional dan pengembaraan kata itu di dalam bahasa-bahasa dunia semenjak abad-abad awal Masehi, sehingga kata (ßÇÝæÑ) adalah satu-satunya kosa kata bahasa Indonesia yang terdapat di dalam al-Quran. Baca Salman Harun, Mutiara al-Quran, h. 168.

40 Alirman Hamzah, Citra Islam di Mata Barat (Sejarah dan Perkembangan Orientalisme (Padang: IAIN "IB" Press, 2003), h. 3.

${ }^{41}$ Muhammad al-Tunji, al-Mu'jam al-Mufassal fi al-Adab (Beirut: Dar al-Kutub al'Ilmiyyah, 1993), h. 785.

42 Pendapat ini merupakan pendapat yang sangat masyhur di Eropa, karena tulisan tulisan Bahasa Arab dan Eropa merupakan dua tulisan yang sama. Adapun orang-orang Yunani mereka mengambil huruf finiqiyyah klasik, kemudian 
memasukkannya ke dalam bahasa Eropa, namun mereka terlebih dahulu melakukan perubahan terhadap bahasa finiqiyyah tersebut, perubahan yang mereka lakukan adalah a. Bahasa finiqiyyah yang selama ini ditulis dari arah kanan ke kiri, mereka merubahnya dari kiri ke kanan, dan b. Mereka menambah vocal dengan "A, I, U, E, O). Baca: Sa'id al-Afghani, Min hadir al-Lughah al'Arabiyyah (Kairo: Dar al-Fikr, 1971), Cet. Ke-2), h. 175.

43 Khalid Muflih 'Isa, al-Lughah al-Arabiyyah Baina Fushah wa al-Ammiyah, h.110.

44 Ramadan 'Abduttawwab, fusul fi Figh al-Lughah, h. 381.

45 Pendapat yang menganggap Islam sangat kental dengan pengaruh Yahudi dan Nasrani merupakan pendapat mayoritas kaum orientalis. Mereka melihat Islam dari kaca mata Yahudi dan Nasrani, sehingga hasilnya jewish heresy atau cristian heresy. Arnold misalnya, mengatakan Islam lahir di gurun pasir, Ibunya sabean Arab, Ayahnya Yahudi dan perawat yang mengasuhnya adalah Kristen Timur. Zwemer juga menyimpulkan bahwa Islam bukanlah sebuah kreatifitas, namun sebuah cangkokan, Islam tidak memiliki kelebihan, kecuali Muhammad yang genius memadukan unsure-unsur lama di dalam obat mujarab baru untuk penyakit manusia dan memaksa manusia masuk ke dalamnya dengan menghunuskan pedang. Baca Eva Ardinal, "Makalah" Orientalis dan Kajian terhadap Bahasa Arab (Padang: tidak diterbitkan, 2008), h. 5.

46 Adnin Armas, "ISLAMIKA" Majalah Pemikiran Islam dan Peradaban Islam (Jakarta: T.tp, 2004), h. 8.

47 Nabilah Lubis mengatakan Filologi adalah pengetahuan tentang sastra-sastra dalam arti luas mencakup bidang bahasa, sastra dan kebudayaan. Lihat: Nabilah Lubis, Naskah, Teks dan Metode Penelitian Filologi (Jakarta: Yayasan Media Alo Indonesia, 2007), Cet. Ke-3, h. 28.

48 http:www.kampusislami.com

49 M. M Al-A'Zami, The History of The Quranic Text From Revelation To Compilation (Jakarta: Gema Insani, 2005), h. 336.

50 Blogs.irenehandono.com

51 Pembahasan tentang sikap yang berkembang pada kalangan ulama terkait kosakata asing dalam al-Quran dapat dijumpai pada buku-buku karya ulama Islam, seperti al-Suyuthi dalam al-Itqân fi Ulûm al-Quran, bahkan al-Suyûthi secara khusus menulis tentang Kosa-kata serapan ini dalam karyanya yang berjudul alMuhazzabu fima waqa'a fi al-Quran min al-Mu'arrab, di samping itu bisa juga dilihat dalam buku al-Mu'arrab min al-kalam al-a'jamiy karya al-Jawaliqi, al-Istiqâq wa al-Ta'rib karya Abd al-Qâdir al-Maghribi, atau bisa juga dilihat dalam karya tokoh non Muslim, seperti Jeffery dalam karyanya yang berjudul The Foreign Vocabulary of The Quran.

52 Burhan al-Din al-Zarkasyi, al-Burhan fi 'Ulum al-Quran, (Beirut: Dar al-Fikr, 1988), h. 359-360.

53 Burhan al-Din al-Zarkasyi, al-Burhan fi 'Ulum al-Quran, (Beirut: Dar al-Fikr, 1988), h. 359-360.

54 Burhan al-Din al-Zarkasyi, a al-Burhan fi 'Ulum al-Quran, (Beirut: Dar al-Fikr, 1988), h. 360. 
55 Jalaluddin 'Abdurrahman al-Suyuti, al-Itqan fi 'Ulum al-Quran, h. 193.

56 Jalaluddin 'Abdurrahman al-Suyuti, al-Itqan fi 'Ulum al-Quran, h. 193-194.

57 Ramadan Abd al-Tawwab, Fusul fi Fiqh al-Lughah, h. 361-362.

58 Ramadan 'Abduttawwab, Fusul fi Fiqh al-Lughah, h. 360.

59 Jalaluddin 'Abdurrahman al-Suyuti, al-Itqan fi 'Ulum al-Quran, h. 194.

${ }^{60}$ Jalaluddin 'Abdurrahman al-Suyuti, al-Itqan fi 'Ulum al-Quran, h. 194.

61 Ramadan 'Abduttawwab, Fusul fi Figh al-Lughah, h. 363.

62 Jalaluddin 'Abdurrahman al-Suyuti, al-Itqan fi 'Ulum al-Quran, h. 195.

\section{DAFTAR PUSTAKA}

al-Quran al-Karim

Abduttawwab, Ramadan, Fusull fi Figh al-Lughah al-Arabiyyah. Kairo: Maktabah alKhaniji, tt.

al-Afghani, Sa'id. 1971. Min hadir al-Lughah al-'Arabiyyah. Kairo: Dar al-Fikr.

AF, Hasanuddin. 1995. Anatomi al-Quran: Perbedaan Qiraat dan Pengaruhnya terhadap Istinbath Hukum dalam al-Quran. Jakarta: PT RajaGrafindo Persada.

Amal, Taufik Adna. 2001. Rekonstruksi Sejarah al-Quran. Yogyakarta: FkBA.

Ardinal, Eva. 2008. "Makalah" Orientalis dan Kajian terhadap Bahasa Arab. Padang: tidak diterbitkan.

Armas, Adnin. 2004. "ISLAMIKA" Majalah Pemikiran Islam dan Peradaban Islam. Jakarta: T.tp,

Al-A'Zami, M. M. 2005. The History of The Quranic Text From Revelation To Compilation. Jakarta: Gema Insani.

Barkah, Abd al-Ghaniy Muhammad Said. 1989. al-l'jaz al-Quraniy: Wujuhu wa Asraruhu. Kairo: Maktabat Wahbat.

Darraz, Muhammad Abdullah, Al-Nab al-'Azhim. Kuwait: Dar al-Qalam, 1974.Gonda, J., Sanskrit in Indonesia. New Delhi: International Academy of India Culture, 1973.

Haugen, Einar. 1956. Billingualism, Language Contact, and Immigrant Languages in the United States. The Hague: Mouton.

Hamzah, Alirman, 2003. Citra Islam di Mata Barat (Sejarah dan Perkembangan Orientalisme). Padang: IAIN “IB" Press.

Harun, Salman. 1999. Mutiara al-Quran, Aktualisasi Pesan Al-Quran dalam Kehidupan. Jakarta: Kaldera.

Ibn Jinni, Abu al-Fath. 1954. 'Uthman, editor Ibrahim Mustafa dan 'Abdullah Amin, al-Munsif. Kairo: Matba'ah al-Babi al-Hilb.

. 1983 M. editor Muhammad 'Ali al-Najjar, al-Khasais. Kairo: al-Hay'ah alMisriyah al-'Ammah li al-Kitab.

'Isa, Khalid Muflih. 1987.al-Lughah al-'Arabiyah baina al-Fushah wa al-'Amiyah. Dar al-Jamahiriyyah li al-Nashri wa al-I'lan.

Ismail, Syaban Muhammad. 1978. Ma' al-Quran al-Karim. Kairo: Dar al-Ittihad alArabiy li al-Thibaat.

Jeffery, Arthur. 1938. Foreign Vocabulary of the Quran. Oriental institute.

Lubis, Nabilah. 2007. Naskah, Teks dan Metode Penelitian Filologi. Jakarta: Yayasan 
Media Alo Indonesia.

Madjid, Nurcholish, 1995. Islam Doktrin dan Peradaban: Sebuah Telaah Kritis tentang

Masalah Keimanan, Kemanusiaan, dan Kemodernan. Jakarta: Paramadina.

al-Mubarak, Muhammad. 1960. Figh al-Lughah al-'Arabiyyah wa Khasaisuha.

Damaskus: Dar al-Fikr.

al-Muhdar dan Bey Arifin, Yunus Ali. 1938. Sejarah Kesustraan Arab. Surabaya: PT.

Bina Ilmu.

al-Rafii, Mushthafa Shadiq. 1998. Tarikh Adab al-Arab. Kairo: Maktabat al-Iman.

Salim, 'Abd al-Faris. Tarikh al-Arab Qabl al-Islam. al-Iskandariyyah, T.tp, tt.

Shihab, M. Quraish. 1996. Membumikan Al-Quran: Fungsi dan Peran Wahyu dalam Kehidupan Masyarakat. Bandung: Mizan.

al-Suyuti, Jalaluddin 'Abdurrahman. 1987. al-Muhadhdhabu fima Waqa'a fi al-Quran min al-Mu'arrab. Beirut: Dar al-Fikr.

al-Suyuti, Jalaluddin 'Abdurrahman. 1426 H. al-Itqan fi 'Ulum al-Quran. Beirut: Majma' al-Mulk.

al-Tunji, Muhammad. 1993. al-Mu'jam al-Mufassal fi al-Adab. Beirut: Dar al-Kutub al-'Ilmiyyah.

Wafi, Abd al-Wahid. 1945. Fiqh al-Lughah. Kairo: Dar Nahdah Misr li al-Tab’i wa al-Nasri.

Watt, W. Wontgomery. 1998. Richard Bell: Pengantar Qur'an, Penerjamah: Lilian D. Tedjasudhana, Judul asli: Bell's Introduction to the Qur'an. Jakarta: INIS.

Weinreich, Uriel. 1953. Languages in Contact: Finding and Problems. The Hague: Mouton.

Ya'qub, Amil Badi'. 1998. Fiqh al-Lughah al-Arabiyyah wa Khasaisuha. Beirut: Dar al-Thaqafat al-Islamiyyah,

Zajuli, Masnal. 2008. al-Ishtirak fi al-Lughah al-'Arabiyyah. Padang: Hayfa Press.

al-Zarkasyi, Burhan al-Din. 1988. al-Burhan fi Ulum al-Quran. Beirut: Dar al-Fikr.

Internet

Blogs.irenehandono.com

http://jamal-alfath.blogspot.com//tarib.html.. di akses pada tanggal 22 April 2014. http:www.kampusislami.com 